\title{
The Influence of Internal Controls on Public Financial Reporting Quality (PFRQ) in Sri Lanka; an Empirical Study
}

\author{
Anuruddha, M.S. ${ }^{1}$, Mahanamahewa, P. ${ }^{2}$ \\ ${ }^{1}$ Sri Lanka Institute of Development Administration, Sri Lanka. \\ ${ }^{2}$ Faculty of Law, University of Technology, Jamaica.
}

\begin{abstract}
Public financial reporting is accountable to maintain public trust by protecting the accountability, openness, and transparency of public money which leads to the good governance of the country. There were many criticisms over financial reporting quality by various stakeholders of entities across the countries. There is a growing concern over the quality of PFR which determines the level of performing expectations of financial reporting. Assurance of PFR in Sri Lanka has deteriorated and been questioned by legislative authorities and interested parties because of the quality concerns. Considering the scholarly studies in various countries, the study was carried out in Sri Lanka to investigate the influence of Internal Controls (ICs) over the Public Financial Reporting Quality (PFRQ) with an objective to measure and conclude the determinants. To conclude the impact, the study investigates the influence of five basic dimensions of ICs introduced in previous literature, namely: Control Environment, Risk Assessment, Control Activities, Information \& Communication, and Monitoring. Considering the facts of the context of Sri Lanka, the research has investigated the influence of IC on public financial reporting quality in the central government ministries and departments environment in Sri Lanka. The primary data was collected by a questionnaire survey conducted with accountants who are being employed in the central government ministries and departments in Sri Lanka. Data have collected by a structured questionnaire and verified by Cronbach's alpha test for reliability. A multiple linear regression model was developed and tested to determine the statistical influence of variables of IC over the dependent PFRQ. The findings investigate and conclude the positively significant influence of IC on the PFRQ in the central government ministries and departments in Sri Lanka. Further, it was admitted the significant direct influence of IC attributes of Control Environment, Information and Communication and Monitoring to determine the PFRQ. Based on the facts, the study recommends the public sector in Sri Lanka to ensure the effectiveness of ICs in government institutions to improve and maintain the trust level of PFRQ.
\end{abstract}

\section{KEYWORDS: Financial Reporting, Public Financial Reporting Quality, Internal Controls}

\section{INTRODUCTION}

Public financial reporting is important to maintain public trust by protecting the accountability, openness, and transparency of public money and facilitating effective and efficient decision making (Oghoghomeh \& Ijeoma, 2014; OAG- Wellington, 2016). According to Olomiyete, and Ayobami, (2014), the key objective of financial reporting in the public sector is maximizing the efficiency of decisions. Stakeholders are able to use financial reports to evaluate the performance of the decisions taken by the officials. Government policy directives are depending on the public trust (Hetherington, 2006), which safeguards the sufficiency of the financial information available for their concerns (Welch, et al. 2005; Waymire et al. 2014). The Canadian Institute of Chartered Accountants (2013) pointed out that, public sector required a multidirectional complex nature financial reporting structure because of the complexity of financial information expectations. Further, the financial information required includes the operational information which explains as today's performance of the entity, and the financial position of the entity which describes the financial condition of the entity at the end of the financial year.

Internal Controls play a vital role in any organization for the protection of effectiveness and efficiency of processes, reliability of financial reporting, and adherence to the existing laws and regulations. It indicates the path to carry out actions and activities in an entity to achieve the said tasks of the financial reporting through five major components; Control Environment, Risk Assessment, Control Activities, Information \& Communication, and Monitoring Activities, which has to be properly designed for the purpose for effective achievements (COSO, 2013).

In the context of public sector financial management in Sri Lanka, financial reporting has been criticized for major lapses. Non-existence of Fixed Assets Registers and Losses \& Damages Registers (CPA, 2013), inability to provide their Revenue Accounts for years (CPA, 2013), lack of full disclosure of government liabilities (CPA, 2013) and some other common limitations that cause erosion in the public trust of the public financial governance. 
Considering those facts, the research has focused on studying the influence of the effectiveness of Internal Controls on Public Financial Reporting Quality. Though, there have been studies regarding the subject in different environments, this study directly engaged with the public sector environment aiming to fill the gap in the literature. This is an empirical analysis of the phenomenon which covers the public sector in Sri Lanka.

This study has been presented in five sections; section one present the introduction of the study. The theoretical background and previous scholarly studies of the study is coming under the section two while section three describes the research design. Section four is data analysis and discussions and finally section five is devoted to conclusion and recommendations.

\subsection{Problem Definition}

In this context, the Internal Controls of an organization becomes a major player to introduce, maintain, and improvements of internal processes to safeguard the organizational interests. The level of influence of Internal Controls on Quality of Public Financial Reporting is debatable and there is a requirement of evidence-based analysis to identify the real influence. The research focuses on this specific gap in the literature to identify the level of effectiveness and the depth influence of Internal Controls and their factors to determine the Public Financial Reporting Quality.

Figure 1.1: Conceptual framework - Level i

Internal Control (IC)

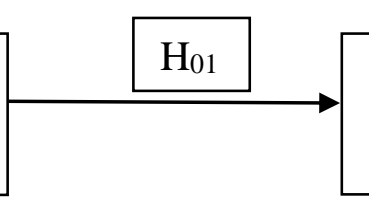

Quality of Public Financial

Reporting

Figure 1.2: Conceptual framework - Level ii

\subsection{Developing Hypothesis}

\subsection{Research Objectives and Questions}

The specific objectives of the research are;

1. To measure the efficiency of Internal Control to determine Public Financial Reporting Quality.

2. To examine the level of influence by the Internal Controls over each Public Financial Reporting Quality characteristic.

\subsection{Research questions}

Having outlined, the research statement, the research questions addressed in this study includes,

1. What is the level of the efficiency of Internal Controls contributing to the Quality of Public Financial Reporting?

2. To what extent the Internal Controls effectively influencing each Public Financial Reporting Quality characteristic?

\subsection{Conceptual Framework}

The first level conceptual framework developed to demonstrate the basic relationship of internal control variable for the public financial reporting quality is shown in Figure 1.1. The second level conceptual framework (Figure 1.2) describes the relationship of independent variables and dimensions which shape each independent variable.

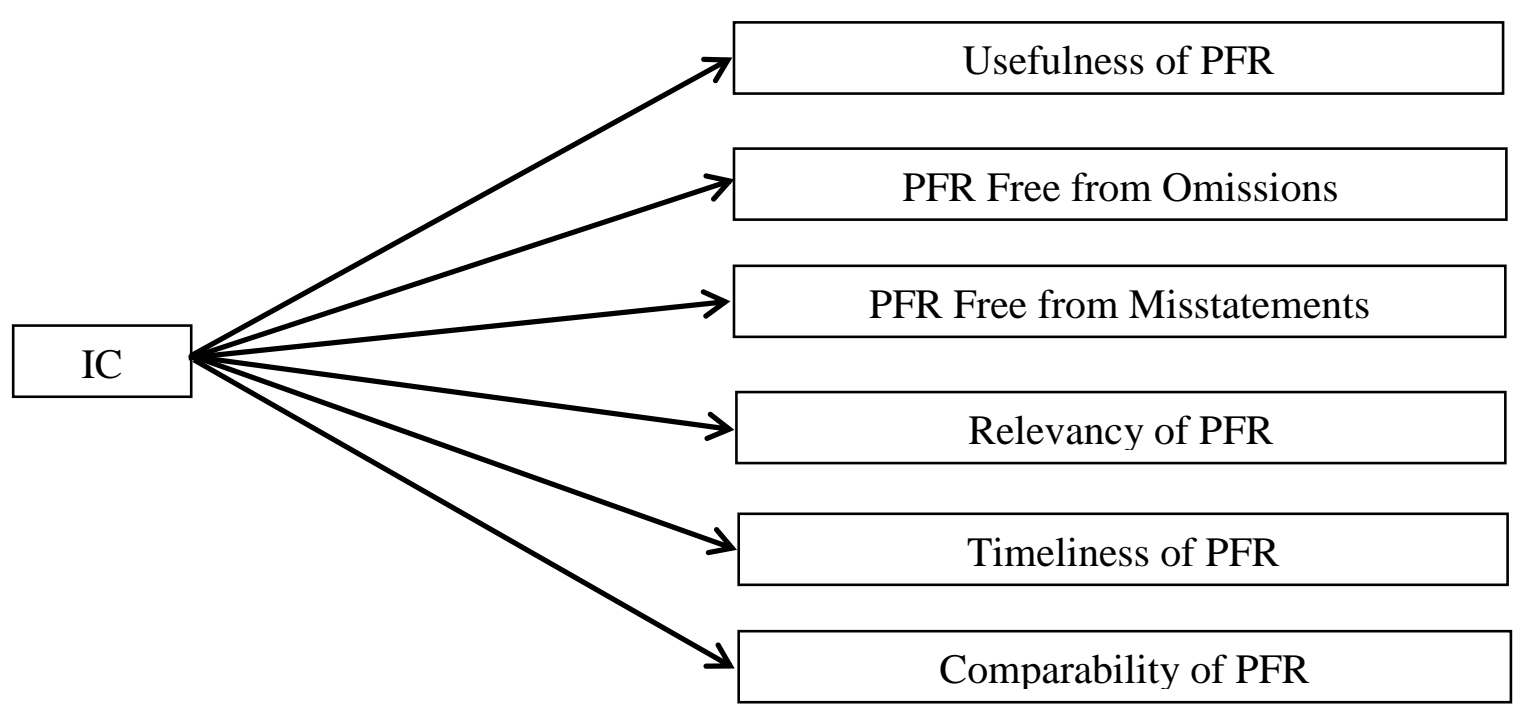

Source: Developed by the Research 
The following hypotheses are developed to test the relationship between the Effectiveness of Internal Controls and PFRQ.

Hypothesis : $\mathrm{H}_{01}$ and $\mathrm{H}_{01 \mathrm{a}}-\mathrm{H}_{01 \mathrm{e}}$

$\mathrm{H}_{01}$; The Efficiency of Internal Control is not positively contributing to the Quality of Public Financial Reporting.

$\mathrm{H}_{01 \mathrm{a}}$; The Control Environment of the Internal Controls is not positively contributing to the Public Financial Reporting Quality.

$\mathrm{H}_{01 \mathrm{~b}}$; The Risk Assessment of the Internal Controls is not positively contributing to the Public Financial Reporting Quality.

$\mathrm{H}_{01 c}$; The Control Activities of the Internal Controls is not positively contributing to the Public Financial Reporting Quality.

$\mathrm{H}_{01 \mathrm{~d}}$; The Information \& Communication of the Internal Controls is not positively contributing to the Public Financial Reporting Quality.

$\mathrm{H}_{01 \mathrm{e}}$; The Monitoring Activities of the Internal Controls is not positively contributing to the Public Financial Reporting Quality.

Hypothesis : $\mathrm{H}_{02 \mathrm{a}}-\mathrm{H}_{02 \mathrm{f}}$

$\mathrm{H}_{02}$; The Efficiency of Internal Control is not positively contributing to the

a. usefulness of Public Financial Reporting.

b. financial reporting free from omission.

c. financial reporting free from misstatements.

d. relevancy of Public Financial Reporting.

e. timeliness of Public Financial Reporting.

f. comparability of Public Financial Reporting.

\subsection{Significance of the Study}

Financial reporting has a significant influence to maintain the principal-agent relationship in the public sector through transparency and ensuring of the effectiveness of public resource utilization decisions. Academics have already found the influence of Internal Controls over the financial reporting quality in different environments. The study focuses on the influence of internal controls over the public financial reporting quality in the Sri Lankan public sector environment. Therefore, this study is very essential to show the effectiveness of the internal controls to determine the public sector financial reporting quality. Finally, the effect of this research will be important for the empirical evidence for the decision-makers in the public sector to establish an effective and efficient public financial reporting system and for the academics for literature development.

\subsection{Scope and Limitation of the Study}

The study specifically focused attention on the central government ministries and departments in Sri Lanka. The questionnaire survey method was applied for the primary data gathering. The study population was accountants who are working in the central government ministries and departments in Sri Lanka. The basic limitation of the study is the limitations of the questionnaire survey method. On the other hand, this study has methodological limitations on its measures of variables; both dependent and independent variables. The research was established according to the perceptions of the accountants' who were working in the central government ministries and departments in Sri Lanka while other stakeholders were left apart.

\section{LITERATURE REVIEW}

\subsection{Public Financial Reporting}

Financial reporting is how public entities account for their stewardship of money and other assets (OAG- Wellington, 2016). Public financial reporting protects the accountability, openness, and transparency of public money while facilitating dicision making in an effective and efficiant way. It helps to improve the performance of the public entities while protecting peoples' trust (OAG- Wellington, 2016). The success of the government policy directives depends on the public trust (Hetherington, 2006), and the trust depends on the sufficiency of the financial information available for their concerns (Welch, et al., 2005; Waymire, et al., 2014).

The direct application of financial reporting is to make economic decisions which are based on the information provided by the financial statements (FASB, 1999; IASB, 2008; Mande, 2015). There is a basic need to develop financial statements in a systematic and precise manner considering the importance to the entity's decision making (Mande, 2015). In the context of public sector enterprises, people keep in touch with the entities performances which is demonstrated by the financial information provided by the reports (OAG- Wellington, 2016). Therefore, financial reports in the Public Sector are being formulated with the objective to provide full disclosure on a timely basis of all material facts relating to government financial position and operations (Achua, 2009; CICA, 2013; Onyinyechi, et al., 2016).

The Canadian Institute of Chartered Accountants (2013) pointed out that there is a multidirectional complex nature in the financial reporting structure required for the public sector because of the complexity of financial information expectations. The financial statements include statement of financial position; statement of financial performances, statement of changes in financial position, notes and other statements and explanatory material that are an integral part of the financial statements (Allen, 2002). 


\subsection{Public Financial Reporting Quality}

As the financial reporting quality denominates a vast subject area, several definitions can be investigated based on the different user perspectives. First such definition investigated was that of Verdi (2006) which defines the subject as "the precision with which financial reports convey information about the firm's operations, in particular its cash flows, in order to inform equity investors". The main financial reporting quality objective is to equip the financial reporting users with the useful, adequate and correct data to the managers for their organizational decisions (IASB, 2008). According to Tasios, (2012), There is a broad role for the financial reporting to provide even-handed financial and other information that together with information of other sources facilitates the efficient and effective utilization of scarce resources for economic development. While Cheung, E., et al. (2010) argues that the quality of financial reporting is a regulatory concept and is generated by the professional and academic discourse. The concept has not been adequately discussed. According to Nyor (2013); Nwaobia et al., (2016), the level of correctness of the operation information provided by the financial reports to enhance the accuracy of the future forecasts of cash flows denominated the financial reporting quality. The studies by Dechow \& Dichev, (2002); Schipper \& Vincent, (2003); Botosan, (2004); Daske \& Gebhardt, (2006); Dechow, et al., (2010) and Gassen \& Schwedler, (2010), have emphasised the multidimensional nature of the concept of financial reporting quality.

As emphasised by Renkas, et al. (2016); Kythreotis, (2014); Palea (2013); Tasios, (2012) and IASB (2010), there are two fundamental qualitative characteristics representing financial reporting quality. Those are relevance and faithful representation which are designed to fulfil the requirement of effective information for different user decisions. Hong, (2016) identifies relevance and reliability as the two fundamental characteristics while other characteristics are presented as matters to enhance the fundamental effects. According to Tasios, (2012); Palea, (2013); Kythreotis, (2014); Renkas, et al. (2016), quality characteristics can be divided into two basic categories as fundamental and enhancing.

The fundamental information on financial reporting is identified as usefulness and relevancy considering the effect for a faithful presentation of information (Hong, 2016; Kythreotis, 2014) When the information provided by the financial reports facilitates an alternative option for the decision makers to take decisions, it is the relevancy of the information (IASB, 2010). Enhancing characteristics are aggravating the effect of fundamental characteristic in the sense of determining the financial reporting quality. As pointed out by Cheung, et al., (2010) Hall (2011); Afiah and Rahmatika (2014), and many others, there are many quality enhancing characteristics such as comparability and timeliness. The enhancing characteristics cannot enhance the decision usefulness of the financial reporting and only the fundamental characteristics can do it. Cheung, et al. (2010), have stated that the financial information should be reliable to be a useful information. Financial information free from omissions and material misstatements basically represent the quality of reliability which the entity faithfully representing for requirements of the user information.

\subsection{Internal Controls (ICs) as a Determinant of Public Financial Reporting Quality}

Because of the complex nature and researcher considerations, assessment of financial reporting quality becomes a difficult task (Dechow and Dichev, 2002). Though it is a difficult task, financial reporting quality becomes an interesting subject discipline for many parties such as accounting standards setters, professionals, as accounting practitioners and researchers because of the importance of the subject (Hong, 2016). Financial reporting provides financial information in an effective, efficiant, reliable and secured manner for the users of the financial reporting. Internal Controls (IC) there to indicate the path to carryout actions and activities in an entity to achieved the said tasks of the financial reporting (Suwanda, 2015).

As Petrovits et al., (2011) explained, there are three main objectives of the internal controls as maintaining effectiveness and efficiency, reliability of financial reporting and encourage adherence to existing laws and regulations. According to Wardiwiyono (2012), the main objective of the ICs is to maintain effectiveness of entity's activities ensuring adherence to the rules and regulations and prevention of frauds, misconducts and omissions. The influence on quality of financial reporting and internal controls were examined and discussed by many scholars such as Dechow et al., (1996); McMullen (1996); Elbanan (2008); Afiah and Rahmatika, (2014). Ramdany, (2015) explained that the effectiveness of the internal control is a major determinant of the quality of financial reporting.

IC is defined as a process of ensuring the entity's achievements of operations, reporting, and compliance by securing the entity's internal parties (COSO, 2013). The process of IC safeguards the assets, completeness of records and transactions, timeliness and operation by reducing the probability of fraud, misconduct and omissions (Lemi, 2015). As admitted by Arens, et al. (2014), IC has direct influence to reduce misstatements in the financial reporting while Lakis and Giriunas (2012), admitting the contribution to the prevention of financial crimes and misconducts. In the public sector application, Bianchi (2010); Liu (2011); Aziz et al. (2014), admitted that the accountability process of public finance has been tremendously influenced by the internal controls of public sector entities.

IC is a multidisciplinary phenomenon (Aziz, et al. 2014). Financial reported supporting by IC has interdependent five major components: Control Environment, Risk Assessment, 
Control Activities, Information \& Communication and Monitoring Activities, which have to be properly designed for the purpose for effective achievements (COSO, 2013). Aren et al. (2014); Afiah and Rahmatika, (2014); Ramdany, (2015), have also admitted the same criteria in their studies.

\section{RESEARCH DESIGN}

The research design refers to the way to effectively address the research problems. In this study, the descriptive research design with the use of basic empirical research is adopted. The primary data collection method used in this research was questionnaire survey. As it has expected to collect data regarding the PFRQ, 5 point Likert scale type questions were used in the survey. The population identified for the survey was the members belonging to the Sri Lanka Accountants' Service who are responsible for the public financial management in the Central Government Ministries and Departments in Sri Lanka.

There are 1,265 accountants coming under the category (source; Sri Lanka Accountants' Service Seniority List published by the Accountants' Service Section, Ministry of Public Administration, Sri Lanka). The research used the Yaro Yamane's sampling size calculation formula to calculate the sample size in this research.

According to the Yaro Yamane's sampling size calculation formula, the sample size was:

$$
\mathrm{n}=\mathrm{N} / 1+\mathrm{N}(\mathrm{e}) 2
$$

$\mathrm{n}=$ Sample size

$\mathrm{N}=$ Population of the study

$\mathrm{e}=$ error margin or level of significance $(5 \%)$

$\mathrm{I}=$ Constant

$\mathrm{N}$, the population was 1265 .

Applying the formula; $\mathrm{n}=$ 303.9

$$
n=
$$

$$
1+1265(0.05) 2
$$

The sample size of this study was determined as 304, and the questionnaire was distributed through postal mail. The research was able to manage $71 \%$ of respond rate in this study (See Table 01).

Table 01: Questionnaire Survey - Response Rate

\begin{tabular}{|c|c|c|c|}
\hline Population & $\begin{array}{c}\text { Survey } \\
\text { Sample }\end{array}$ & $\begin{array}{c}\text { No of } \\
\text { Responses }\end{array}$ & $\begin{array}{c}\text { Response } \\
\text { Rate } \%\end{array}$ \\
\hline 1,265 & 304 & 217 & 71 \\
\hline
\end{tabular}

Source: Developed by the Researcher

Influence of Internal Controls over PFRQ was conceptualized in a Multiple Regression Model. Collected data was summarized, coded and entered into the Microsoft
Office Excel spreadsheets before entering to the Statistical Package for Social Sciences (SPSS) version 20.0. The data were analysed using the statistical descriptive analysis, reliability test and multiple correlation analysis. Research hypothesis was tested based on the multiple linear regression analysis technique which is the most suitable technique to test the data in the subject of this nature.

\section{DATA ANALYSIS}

\subsection{Findings of Reliability}

Establishing internal consistency ensures that the individual items or indicators of the scale measure a similar construct and will thus be highly inter-correlated in the research. The indication of how consistent and how close multiple measurements of a variable are to each other is given by Cronbach's Alpha, and is referred to as 'internal consistency' (Cronbach, 1951, Hair et al. 2009). Considering the suggestion of Pallant, (2007), the study has decided to fix the Cronbach's Alpha value more than 0.6 as the satisfactory level. Table 02 provides details of the Alpha value of pilot and final survey scores for the two main variables of the study. As seen in Table, the alpha coefficient for the IC variable was 0.877 for the measurements considered under the variable and Cronbach's Alpha for the Variable Quality of Public Financial Reporting was 0.605 .

Table 02 : Cronbach's Alpha Test Results

\begin{tabular}{|l|c|c|c|}
\hline Variables & $\begin{array}{c}\text { No. of } \\
\text { measurements }\end{array}$ & $\begin{array}{c}\text { No. } \\
\text { of } \\
\text { Cases }\end{array}$ & $\begin{array}{c}\text { Cronbach's } \\
\text { Alpha }\end{array}$ \\
\hline Internal Control & 35 & 214 & 0.877 \\
\hline $\begin{array}{l}\text { Quality of Public } \\
\begin{array}{l}\text { Financial } \\
\text { Reporting }\end{array}\end{array}$ & 06 & 214 & 0.605 \\
\hline
\end{tabular}

Source: Developed by the Researcher

\subsection{Multiple Regression Analysis for the Variables}

The research utilizes multiple regression statistical technique as an analytical tool. Pallant, (2016) emphasize that the multiple regression as the best method of analysing the correlations among variables in a multi dimensioned complex nature in real life. The research developed and tested six different models to identify the relationship of variables. The models tested in this regard were shown in Table 03 .

Table 03: Multiple Regression Models

\begin{tabular}{|l|l|l|l|}
\hline Model & Dependent Variables & \multicolumn{2}{|l|}{ Independent Variables } \\
\hline Model i & Public Financial Reporting Quality & \multirow{2}{*}{ Internal Controls (IC) } & Control Environment \\
\cline { 1 - 2 } Model ii & Usefulness of Public Financial Reporting & & \\
\hline
\end{tabular}


"The Influence of Internal Controls on Public Financial Reporting Quality (PFRQ) in Sri Lanka; an Empirical Study"

\begin{tabular}{|c|c|c|}
\hline Model iii & $\begin{array}{l}\text { Public Financial Reporting free from } \\
\text { serious omissions }\end{array}$ & Risk Assessment \\
\hline Model iv & $\begin{array}{l}\text { Public Financial Reporting free form } \\
\text { Misstatements }\end{array}$ & Control Activities \\
\hline Model v & Relevancy of Public Financial Reporting & Information \\
\hline Model vi & Timeliness of Public Financial Reporting & Communication \\
\hline Model vii & $\begin{array}{l}\text { Comparability of Public } \text { Financial } \\
\text { Reporting }\end{array}$ & Monitoring Activities \\
\hline
\end{tabular}

Source: Developed by the Researcher

\subsubsection{Testing for Multicolinearity}

The independent variables were tested for the multicollinearity. The correlation between each independent variable or whether each independent variable is independent from each other is tested by the multicolinearity
(Argyrous, 2014). According to Pallant, (2016), Pearson Correlation $\geq 0.9$ in the multiple regression analysis indicates the problem while calculated maximum correlation (Table 04) indicates 0.510 at $95 \%$ confidence level expressing that no multicolinearity problem exist.

Table 04: Pearson Correlations between variables

\begin{tabular}{|l|c|c|c|c|c|}
\hline & $\begin{array}{c}\text { Control } \\
\text { Environment }\end{array}$ & $\begin{array}{c}\text { Risk } \\
\text { Assessment }\end{array}$ & $\begin{array}{c}\text { Control } \\
\text { Activities }\end{array}$ & $\begin{array}{c}\text { Information \& } \\
\text { Communication }\end{array}$ & $\begin{array}{c}\text { Monitoring } \\
\text { Activities }\end{array}$ \\
\hline Control Environment & 1.000 & & & & \\
\hline Risk Assessment & .337 & 1.000 & & & \\
\hline Control Activities & .281 & .493 & 1.000 & & \\
\hline Information \& Communication & .232 & .279 & .330 & .000 & \\
\hline Monitoring Activities & .218 & .395 & .246 & .510 & 1.000 \\
\hline
\end{tabular}

Source: Developed by the Researcher

\subsubsection{Multiple Regression Analysis - Model i}

The Model i tested the relationship between quality of public financial reporting against each factor of the Internal Controls; Control Environment, Risk Assessment, Control Activities, Information \& Communication and Monitoring Activities. The F-Test in the analysis established the relationship of independent variables $(\mathrm{X})$ with the dependent variable $(\mathrm{Y})$ which demonstrated the model fit 13.249> $\mathrm{F}$ table $(\alpha=0.05) 2.21$ significant at $\mathrm{P}=0.000$ and $\mathrm{F}=18.303$ (Table 05) which implies that there was strong relationship between the predictors and the outcomes of the regression variable. The values are used to answer the question "Is the efficiency of IC is positively contributing to the Quality of Public Financial Reporting?". Therefore, it can be reliably predicting that the independent variable Efficiency of Internal Control are been reliably contributing to improve PFRQ. In this analysis, independent variable has indicated $\mathrm{R}$ value of 0.491 expressing the relationship between independent variables and dependent variable (Steel and Torrie, 1960). According to the findings R Square value the independent variable has influenced $24.2 \%$ of the variations of the dependent public financial reporting quality.

Table 05: Regression Model Test Result (Model i)

\begin{tabular}{|l|c|c|c|c|c|}
\hline Model & R & R Square & F & Sig. & F Table Value \\
\hline Model i & 0.491 & 0.242 & 13.249 & 0.000 & 2.21 \\
\hline
\end{tabular}

Source: Developed by the Researcher

The effect of each finding over the Hypothesis $\mathrm{H}_{01}$ has summarized in Table 06.

Table 06: Results for Hypothesis $\mathrm{H}_{01}$

\begin{tabular}{|l|l|l|}
\hline \multicolumn{2}{|l|}{ Hypothesis } & Results \\
\hline $\mathrm{H}_{01}$ & $\begin{array}{l}\text { The Efficiency of Internal Control is not positively contributing to the Quality } \\
\text { of Public Financial Reporting. }\end{array}$ & Rejected \\
\hline
\end{tabular}

Source: Developed by the Researcher

Statistical significance of each of the factors of the Internal Controls is demonstrated by the T-test in the multiple regression analysis. The t-value and corresponding $\mathrm{p}$-value in the coefficients in regression output indicate the statistical significance of each independent variable. The calculated Beta values in the Table 07 indicate the constant value and 
the level of influence which can be applied to the multi regression as:

PFRQ $=1.226+0.109$ Control Environment +0.041 Risk Assessment +0.029 Control Activities +0.078 Information $\&$ Communication +0.137 Monitoring Activities $+\infty$.

The statistical significance of each independent variable has been decided by the $\mathrm{p}$ value in the table. As expressed by Pallant, (2016), the variable having $\mathrm{p}$ value $>0.05$ is considered as statistically insignificant. According to the results, Control Environment, Information \& Communication and Monitoring Activities have indicated $\mathrm{p}$ value $>0.05$ which expresses that the variables strongly contributed to determine the PFRQ while other two variables; Risk Assessment and Control Activities, failed to prove the statistical significance of their influence.

Table 07: Multiple Regression T-test Results (Model i)

\begin{tabular}{|l|c|c|c|c|}
\hline Model & Unstandardized Beta Coefficients & Standardized Beta Coefficients & T & Sig. \\
\hline (Constant) & 1.226 & & 9.452 & .000 \\
\hline Control Environment & .109 & .182 & 2.780 & .006 \\
\hline Risk Assessment & .041 & .079 & 1.056 & .292 \\
\hline Control Activities & .029 & .063 & 0.883 & .378 \\
\hline Information \& Communication & .078 & .152 & .038 \\
\hline Monitoring Activities & .137 & .230 & .086 & .038 \\
\hline
\end{tabular}

Source: Developed by the Researcher

The identified unique relationship was tested for individual effect and the uniqueness of hypothesized relationships by T-Test analysis of SPSS statistics and whether the hypothesis is being accepted or rejected is shown in the Table 08.

The independent variable Control Environment of the Internal Controls indicate T Count $2.780>\mathrm{t}$ table $(\alpha=0.05)$ for 1.6449 and the regression coefficient 0.109 indicates a statistically significant $($ Sig. $=0.006)$ relationship.

The value of $t$ count in Risk Assessment of the IC variable is $1.056<\mathrm{t}$ table $(\alpha=0.05)$ for 1.6449 and the regression coefficient is positive $(0.041)$ at $\mathrm{Sig} .=0.292$ (insignificant). The results were not constructed a unique influence on PFRQ.
The independent variable Control Activities of the Internal Controls shows $\mathrm{T}$ Count $0.883<\mathrm{t}$ table $(\alpha=0.05)$ for 1.6449 and regression coefficient 0.029 indicating statistically insignificant relationship (Sig.=0.378).

The $\mathrm{T}$ Count in Information \& Communication of the Internal Controls variable $2.086>\mathrm{t}$ table $(\alpha=0.05)$ for 1.6449 while regression coefficient indicates positive, (0.078) statistically significant $($ Sig. $=0.038)$ relationship.

The $\mathrm{T}$ Count in Monitoring Activities of the Internal Controls variable is $3.116<\mathrm{t}$ table $(\alpha=0.05)$ for 1.6449 while regression coefficient indicates a positive, (0.137) statistically significant $(\mathrm{Sig} .=0.002)$ relationship.

The effect of the each findings over the hypotheses $\mathrm{H}_{01}$. $\mathrm{H}_{02 \mathrm{a}}, \mathrm{H}_{03 \mathrm{a}}$ and $\mathrm{H}_{04 \mathrm{a}}$ has summarized in Table 08.

Table 08: Results for Hypotheses $\mathrm{H}_{01 \mathrm{a}}$. $\mathrm{H}_{02 \mathrm{a}}, \mathrm{H}_{03 \mathrm{a}}$ and $\mathrm{H}_{04 \mathrm{a}}$

\begin{tabular}{|l|l|l|}
\hline \multicolumn{2}{|l|}{ Hypothesis } & Results \\
\hline $\mathrm{H}_{01 \mathrm{a}}$ & $\begin{array}{l}\text { The Control Environment of the Internal Controls is not positively contributing } \\
\text { to the Public Financial Reporting Quality. }\end{array}$ & Rejected \\
\hline $\mathrm{H}_{01 \mathrm{~b}}$ & $\begin{array}{l}\text { The Risk Assessment of the Internal Controls is not positively contributing to } \\
\text { the Public Financial Reporting Quality. }\end{array}$ & Accepted \\
\hline $\mathrm{H}_{01 \mathrm{c}}$ & $\begin{array}{l}\text { The Control Activities of the Internal Controls is not positively contributing to } \\
\text { the Public Financial Reporting Quality. }\end{array}$ & Accepted \\
\hline $\mathrm{H}_{01 \mathrm{~d}}$ & $\begin{array}{l}\text { The Information \& Communication of the Internal Controls is not positively } \\
\text { contributing to the Public Financial Reporting Quality. }\end{array}$ & Rejected \\
\hline $\mathrm{H}_{01 \mathrm{e}}$ & $\begin{array}{l}\text { The Monitoring Activities of the Internal Controls is not positively } \\
\text { contributing to the Public Financial Reporting Quality. }\end{array}$ & Rejected \\
\hline
\end{tabular}

Source: Developed by the Researcher

\subsubsection{Multiple Regression Analysis - Model ii - vi}

Multiple Regression Models ii - vii were tested to explore the independent efficiency of Internal Control over the dependent variables; Usefulness of Public Financial Reporting, Public Financial Reporting free from serious omissions, Public Financial Reporting free form
Misstatements, Relevancy of Public Financial Reporting, Timeliness of Public Financial Reporting and Comparability of Public Financial Reporting. F test of the study has been indicated in the Table 09. The effect of each can be describes as; 
F test for regression Model ii which describe the relationship of the independent variable Efficiency of Internal Control and dependent Usefulness of Public Financial Reporting indicate that the F count is $5.252>\mathrm{F}$ table $(\alpha=0.05) 2.21$ at $\mathrm{p}=0.000$ recognizing the statistically significant relationship. It is further recognized that the independent variable effectively associated with the dependent variable which contributes $11.2 \%$ of the movements of the dependent variable indicating considerable level of influence.

$F$ test for regression Model iii which describe the relationship of the independent variable Efficiency of Internal Control and dependent Public Financial Reporting free from serious omissions indicate that the $F$ count is $3.093>$ F table $(\alpha=0.05) 2.21$ at $p=0.010$ recognizing the statistically significant relationship. It is further recognized that the independent variable is effectively associated with the dependent variable which contributes $6.9 \%$ of the movements of the dependent variable indicating fairly considerable level of influence.

$F$ test for regression Model iv which describe the relationship of the independent variable Efficiency of Internal Control and dependent Public Financial Reporting free from Misstatements indicate that the F count is $3.237>$ $\mathrm{F}$ table $(\alpha=0.05) 2.21$ at $\mathrm{p}=0.008$ recognizing the statistically significant relationship. It is further recognizing that the independent variable effectively associated with the dependent variable which contributes $7.2 \%$ of the movements of the dependent variable indicating considerable level of influence.

$\mathrm{F}$ test for regression Model $\mathrm{v}$ which describe the relationship of the independent variable Efficiency of Internal Control and dependent Relevancy of Public Financial Reporting indicate that the F count is $10.461>\mathrm{F}$ table $(\alpha=0.05) 2.21$ at $\mathrm{p}=0.000$ recognized the statistically significant relationship. It is further recognizing that the independent variable is effectively associated with the dependent variable which contributes $20.1 \%$ of the movements of the dependent variable indicating high level of influence.

F test for regression Model vi which describes the relationship of the independent variable Efficiency of Internal Control and dependent Timeliness of Public Financial Reporting indicate that the $\mathrm{F}$ count is $1.551>\mathrm{F}$ table $(\alpha=0.05) 2.21$ at $p=0.176$ recognizing the statistically insignificant relationship. It is further recognized that the independent variable associated with the dependent variable which contributes $3.6 \%$ of nominal influence.

F test for regression Model vii which describes the relationship of the independent variable Efficiency of Internal Control and dependent Comparability of Public Financial Reporting indicate that the F count is $4.124>\mathrm{F}$ table $(\alpha=0.05) 2.21$ at $p=0.001$ recognized the statistically significant relationship. It is further recognizing that the independent variable is effectively associated with the dependent variable which contributes $9.0 \%$ of the movements of the dependent variable indicating fairly considerable level of influence.

Table 09: Regression Model Test Result (Model ii - vii)

\begin{tabular}{|l|c|c|c|c|c|}
\hline Model & R & R Square & F & Sig. & F Table Value \\
\hline Model ii & 0.335 & 0.112 & 5.252 & 0.000 & 0.010 \\
\hline Model iii & 0.263 & 0.069 & 3.093 & 0.008 \\
\hline Model iv & 0.269 & 0.072 & 3.237 & 0.000 \\
\hline Model v & 0.448 & 0.201 & 10.461 & 0.176 \\
\hline Model vi & 0.190 & 0.036 & 1.551 & 0.001 \\
\hline Model vii & 0.300 & 0.090 & 4.124 & \\
\hline
\end{tabular}

Source: Developed by the Researcher

The effect of each finding over the Hypothesis $\mathrm{H}_{02 \mathrm{a}}-\mathrm{H}_{02 \mathrm{f}}$ has summarized in Table 10 .

Table 10: Results for Hypothesis; $\mathrm{H}_{02 \mathrm{a}}-\mathrm{H}_{02 \mathrm{f}}$

\begin{tabular}{|l|l|l|}
\hline \multicolumn{2}{|l|}{ Hypothesis } & Results \\
\hline $\mathrm{H}_{02 \mathrm{a}}$ & $\begin{array}{l}\text { The Efficiency of Internal Control is not positively contributing to the } \\
\text { usefulness of Public Financial Reporting. }\end{array}$ & Rejected \\
\hline $\mathrm{H}_{02 \mathrm{~b}}$ & $\begin{array}{l}\text { The Efficiency of Internal Control is not positively contributing to the } \\
\text { Financial Reporting free from omission. }\end{array}$ & Rejected \\
\hline $\mathrm{H}_{02 \mathrm{c}}$ & $\begin{array}{l}\text { The Efficiency of Internal Control is not positively contributing to the } \\
\text { Financial Reporting free from misstatements. }\end{array}$ & Rejected \\
\hline $\mathrm{H}_{02 \mathrm{~d}}$ & The Efficiency of Internal Control is not positively contributing to the & Rejected \\
\hline
\end{tabular}




\begin{tabular}{|l|l|l|}
\hline & relevancy of Public Financial Reporting. & \\
\hline $\mathrm{H}_{02 \mathrm{e}}$ & $\begin{array}{l}\text { The Efficiency of Internal Control is not positively contributing to the } \\
\text { timeliness of Public Financial Reporting. }\end{array}$ & Accepted \\
\hline $\mathrm{H}_{02 \mathrm{f}}$ & $\begin{array}{l}\text { The Efficiency of Internal Control is not positively contributing to the } \\
\text { comparability of Public Financial Reporting. }\end{array}$ & Rejected \\
\hline
\end{tabular}

Source: Developed by the Researcher

\section{CONCLUSION RECOMMENDATIONS}

The primary objective of the study was to identify the level of effectiveness and the depth influence of Internal Controls and their factors to determine the Public Financial Reporting Quality. The research was motivated by the issues arisen in the context of public financial reporting in Sri Lanka.

It was concluded that, the Public Financial Reporting Quality is key to analyse and decision making in public sector organizations and has a macroeconomic effect. It has effective contribution to the public trust leading to accountability and transparency over the effective and efficient utilization of public money. The Public Financial Reporting Quality has been significantly influenced by the effectiveness of the Internal Controls. The improvements of the Control Environment, Information and Communication and Monitoring Activities of the Internal Control has direct influence on improving the Public Financial Reporting Quality. On the other hand, overall improvement of all factors of the Internal Controls has direct effect on upgrading the levels of the dimensions of the Public Financial Reporting Quality such as Usefulness of Public Financial Reporting, Public Financial Reporting free from serious omissions, Public Financial Reporting free form Misstatements, Relevancy of Public Financial Reporting and Comparability of Public Financial Reporting. The findings will provide a basis for the policy makers of the governments to develop internal control regulations, procedures and measurements for the public sector.

There have been concerns over the quality of public financial reporting in Sri Lanka. Improvements of the effectiveness of Internal Controls may help to improve the quality levels of public financial reporting in the country. Considering the above facts, government should introduce required regulatory measures to strengthen the Internal Controls of the public sector and effectively implement the measures to enhance the level of PFRQ.

Finally, it is expected to test the results of the study in different environments and countries to further refine the relationship of Internal Controls over the Public Financial Reporting Quality in future studies.

\section{REFERENCES}

1. Achua, J.K. (2009). "Reinventing Governmental Accounting for Accountability Assurance in Nigeria", Nigeria Research Journal of Accountancy, 1(1): 1-16.
2. Afiah N.N. and Rahmatika D.N. (2014), Factors Influencing the Quality of Financial Reporting and its Implications on Good Government Governance (Research on Local Government Indonesia), International Journal of Business, Economics and Law, Vol. 5, Issue 1.

3. Allen T.L., (2002), Public Accountability and Government Financial Reporting, Models of Public Budgeting and Accounting Reform, OECD Journal on Budgeting, Volume 2/Supplement 1.

4. Arens, A, A., Elder, R, J., and Beasley, M, S. (2014), Auditing and Assurance Services: An Integrated Approach. Fifteenth Edition. Pearson Education, Essex: England.

5. Aziz, M. A.A., Said, J., and Alam, M.M. (2014), Assessment of the Practices of Internal Control System in the Public Sectors of Malaysia, AsiaPacific Management Accounting Journal, Volume 10 Issue 1

6. Baxter (2007), Audit Committees and financial reporting quality, $\mathrm{PhD}$ Dissertation Thesis, University of Queensland, Australia.

7. Bianchi, C. (2010), Improving performance and fostering accountability in the public sector through system dynamics modelling: From an "external" to an "internal" perspective, Systems Research and Behavioral Science, 27; 361-384.

8. Botosan, C. (2004), Discussion of a framework for the analysis of risk communication, The International Journal of Accounting, 39(3), 289295.

9. Cheung, Evans, E and Wright, S. (2010), An historical review of quality in financial reporting in Australia Esther, Pacific Accounting Review, Vol. 22 No. 2, 2010, pp. 147-169.

10. CICA (2013), Measuring Financial Performance in Public Sector Financial Statements, Conceptual Framework Task Force, Canada Institute of Chartered Accountants (CICA), 277 Wellington Street West, Toronto, Ontario M5V 3H2.

11. COSO, (2013), Internal Control-Integrated Framework, Committee of Sponsoring Organizations of the Treadway Commission, Coopers and Lybrand, New York, NY

12. CPA, (2013), Parliamentary Series No. 204, $1^{\text {st }}$ Report from the Committee on Public Accounts, The Seventh Parliament of the Democratic Socialist Republic of Sri Lanka. 
13. CPA, (2015), Parliamentary Series - No: 376, $1^{\text {st }}$ Session - third report at 2015, The Committee on Public Accounts (CPA), Parliament of the Democratic Socialist Republic of Sri Lanka.

14. Daske, H., \& Gebhardt, G. (2006), International financial reporting standards and experts' perceptions of disclosure quality, Abacus, 42(3-4), 461-498.

15. Dechow, P., \& Dichev, I. (2002), The quality of accruals and earnings: The role of accrual estimation errors, The Accounting Review, 77, 3559.

16. Dechow, P., Ge, W., \& Schrand, C. (2010). Understanding earnings quality: A review of the proxies, their determinants and their consequences. Journal of Accounting and Economics, 50(2-3), 344-401.

17. Dechow, P. M., Sloan, R. G., \& Sweeney, A. P. (1996). Causes and consequences of earnings manipulation: An analysis of firms subject to enforcement actions by the SEC, Contemporary Accounting Research, 13(1), 1-36.

18. Elbanan, M. (2008), Quality of Internal Control over Financial Reporting, Corporate Governance and Credit Rating, International Journal of Disclosure and Governance, 127 - 149.

19. FASB (1999). International standard setting: a vision for the future, Norwalk

20. Gassen, J., \& Schwedler, K. (2010). The decision usefulness of financial accounting measurement concepts: Evidence from an online survey of professional investors and their advisors. European Accounting Review, 19(3), 495-509.

21. Hall, J.A. (2011), Accounting Information Systems, Seventh Edition, South-Western Cengage Learning, USA.

22. Hetherington, M. J. (2006), Why trust matters: Declining political trust and the demise of American liberalism. Princeton, NJ: Princeton University Press.

23. Hong, N.T.P. (2016), The Determinants of Financial Statement Quality of Companies Listed on Stock Market Evidence in Vietnam, University of Economics, Ho Chi Minh City, Vietnam.

24. Horngren, C.T., Harrison, W.T. and Bamber, L.S. (2002), Accounting (5th edition), New Jersey, Prentice Hall, Inc.

25. IASB, (2008), Exposure Draft on an Improved Conceptual Framework for Financial Reporting: The Objective of Financial Reporting and Qualitative Characteristics of Decision-useful Financial Reporting Information, London.
26. Jonas, G.J. and Blanchet, J., (2000), Assessing Quality of Financial Reporting, American Accounting Association.

27. Kythreotis, A. (2014), Measurement of Financial Reporting Quality Based on IFRS Conceptual Framework's Fundamental Qualitative Characteristics, European Journal of Accounting, Finance \& Business, Volume 2/2014, Issue (3).

28. Lakis, V. and Giriunas L. (2012), The Concept of Internal Control System: Theoretical Aspect, ISSN 1392-1258. Ekonomika, 2012 Vol. 91(2).

29. Lemi T., (2015), Assessment of Internal Control Effectiveness in Selected Ethiopian Public Universities, (Unpublished Thesis for the Degree of Masters of Science), Department of Accounting and Finance, School of Graduate Studies, Addis Ababa University.

30. Liu, O. (2011) Outcomes assessment in higher education: Challenges and future research in the context of voluntary system of accountability. Educational Measurement: Issues and Practice, 30; 2-9.

31. Mande, B., (2015), Perceptions on Government Financial Reporting in Nigeria, Journal of Finance, Accounting and Management, Volume 6(1), pp. 122.

32. McMullen, D. (1996), Audit committee performance: An investigation of the consequences associated with audit committees, Auditing, 15(1), 87-103.

33. Nwaobia A. N., Kwarbai J. D., Jayeoba, O. O. and Ajibade A. T., (2016), Financial Reporting Quality on Investors' Decisions, International Journal of Economics and Financial Research, Vol. 2, No. 7, pp: 140-147.

34. OAG- Wellington, (2016), Improving financial reporting in the public sector, Office of the Auditor-General, PO Box 3928, Wellington 6140, Telephone: (04) 917 1500, February 2016.

35. Oghoghomeh, T. \& Ijeoma, N. B., (2014), Adoption of international public sector accounting, Journal of Investment and Management, Volume 3(1), pp. 21-29

36. Onyinyechi, O. C. \& Okafor, M., (2016), Efficiency and Accountability of Public Sector Revenue and Expenditure in Nigeria (1970-2014), European Journal of Accounting, Auditing and Finance Research, 4(7), pp. 23-42.

37. Palea, V. (2013), IAS/IFRS and financial reporting quality: Lessons from the European experience, China Journal of Accounting Research, 6 (2013) 247-263.

38. Petrovits, C., Catherine, S. and Aimee S. (2011), The Causes and Consequences of Internal Control 
Problems in Non-profit Organizations, Accounting Review, Jan 2011, Vol. 86 Issue 1, p325-357.

39. Ramdany, (2015), Influence The Quality of Accounting Information Systems and The Effectiveness of Internal Control On Financial Reporting Quality, Research Journal of Finance and Accounting, Vol.6, No.6, 2015.

40. Renkas, J., Goncharenko, O. and Lukianets, O. (2016), Quality of financial reporting: approaches to measuring, International Journal of Accounting and Economics Studies, 4 (1) (2016) 1-5.

41. Suwanda D. (2015), Factors Affecting Quality of Local Government Financial Statements to Get Unqualified Opinion (WTP) of Audit Board of the Republic of Indonesia (BPK), Research Journal of Finance and Accounting, Vol.6, No.4, 2015.

42. Tasios, S. (2012), Auditor's perceptions of financial reporting quality: the case of Greece, International Journal of Accounting and Financial Reporting, Vol. 2, No. 12012.

43. TISL, (2014), Sri Lanka Governance Report 2012/13, Transparency International, Sri Lanka,

44. Verdi, R. S., (2006), Financial Reporting Quality and Investment Efficiency (September 9, 2006).

Available at SSRN:

https://ssrn.com/abstract=930922 or

http://dx.doi.org/ 10.2139/ssrn.930922 .
45. Wardiwiyono, S. (2012), Internal control system for Islamic micro financing: An exploratory study of Baitul Maal wat Tamwil in the City of Yogyakarta Indonesia, International Journal of Islamic and Middle Eastern Finance and Management, 5(4); 340-352.

46. Waymire T.R., Sohl, S.N. and Howard B. (2014), Public Administrators' Understanding of External Financial Reporting: It Begins With Curriculum, Journal of Public Affairs Education, JPAE 21 (2), 281-294.

47. Welch, E.W., Hinnant, C.C., \& Moon, M.J. (2005), Linking citizen satisfaction with e-government and trust in government, Journal of Public Administration Research and Theory, 15(3), 371392.

48. Zheng, X. (2010), A Comparative Study of Financial Reporting Quality, Business and Management 2010, 6th International Scientific Conference, May 13-14, 2010, Vilnius, Lithuania, doi:10.3846/bm.2010.039. 